\title{
INTERJÚ GEORGES BENKO-VEL, az Espaces et sociétés és a Society and Space szerkesztốbizottságának tagjával
}

\section{Ki Ön, Georges Benko?}

Az Université de Paris I Panthéon-Sorbonne földrajz tanszékének tanára vagyok; gazdaságés társadalomföldrajzot oktatok. Általában regionális gazdaságföldrajzi témákról tartok elōadásokat, másrészt pedig szemináriumokat vezetek doktori disszertációjukon dolgozó aspiránsoknak, évente változó tárgykörökben. Ezenkívül részt veszek az egyetem mellett múködổ Iparés Területfejlesztési Kutató Központ (CRIA) munkájában is. Nemrégiben jelent meg az a francia nyelvữ kötet, amelyet egy nemzetközi kollokviumon elhangzott elóadások alapján szerkesztettem , A társadalomelmélet új aspektusai” címmel (Les nouveaux aspects de la théorie sociale, Caen: Paradigme 1988). Végül, de nem utolsó sorban tagja vagyok a címben jelzett két társadalomföldrajzi folyóirat szerkesztốbizottságának: a francia nyelvử Espaces et sociétés-nek és az angol nyelven megjelenô Society and Space-nek.

Hogyan született e két folyóirat? Kinek vagy kiknek az ambíciói hivták életre és milyen céllal?

Kezdem talán az , ,idôsebbikkel”. Az Espaces et sociétés-t a híres francia filozófus és szociológus, Henri Lefebvre kezdeményezése nyomán alapították 1970 -ben. Lefebvre figyelme a hatvanas évek vége felé ugyanis mindinkább a szociológia irányába fordult, ezen belül is elsôsorban a vidék társadalmi problémái izgatták, majd késóbb egyre több publikációja foglalkozott a városfejlesztés, az urbanizáció kérdéseivel. Olyan politológusokat, szociológusokat, építészeket gyưjtött maga köré, akik érzékenynek bizonyultak a társadalmi jelenségek vizsgálatának újonnan felfedezett dimenziója, nevezetesen a térbeliség iránt. Az Espaces et sociétés legelsố számát nyitó cikkében Lefebvre úgy fogalmaz, hogy a társadalom kutatóit mindaddig elsốsorban az idô problémája foglalkoztatta, a szociológusok számára is az idổbeli változások adták a jelenségek vizsgálatának keretét; a valóság megértéséhez azonban legalább ilyen fontos az is, hogy ismerjük, hogyan reprodukálódik a társadalom a térben, kik és milyen eszközökkel irányítják a térhasználat különbözổ formáit. (Persze azért akadtak már korábban is társadalomtudósok, akik a tér problematikájának is különös figyelmet szenteltek, így például a kiváló francia történész, Ferdinand Braudel.) Kezdetben Manuel Castells, spanyol származású francia szociológus is részt vett a folyóirat szerkesztésében. Ôt mindmáig az egyik legsikeresebb francia városszociológusként tartják számon, noha már tíz éve az Egyesült Államokban él.

A Society and Space-t 1983-ban alapították, jórészt angolszász geográfusok. A tudományos folyóirat a Pion Kiadó ismert társadalomtudományi sorozata, az Environment and Planning D jelû́ részeként jelenik meg. Azzal az ambiciózus céllal szerveződött, hogy a humán geográfia elméleti problémáinak vitafórumává váljon, s ez — úgy vélem - sikerült is. A teljesítményeik alapján joggal magabiztos angol társadalomföldrajzosok - a társadalomtudományok egyete- 
mességét alapul véve - olyan pozíciót kívánnak a geográfiának elérni, amely kölcsönösséget biztosít a társadalom térbeli folyamatait és struktúráit elemzố más tudományágakkal; vagyis ahol a földrajz nemcsak építkezik más diszciplínák ismereteibốl, de hozzá is járul azok fejlổéséhez. Sớt, a Society and Space szerkesztới a társadalomelmélet általános fejlódésében is kiemelkedô szerepet szánnak a folyóirat hasábjain megjelenố vitáknak.

Milyen szerkesztôi politikát követ a két folyóirat? Kötódnek-e a ma múködó szerkesztóbizottságok valamely társadalomelméleti iskolához? Miben tér el a két folyóirat szellemisége, arculata egymástól?

A két tudományos szemle stílusának, arculatának különbségeit mindenekelốtt az angol és a francia földrajz, sốt tágabb értelemben a térbeli kutatások egész körének eltérố helyzete magyarázza. Hiába múködik ugyanis mindkét folyóirat élén nemzetközi szerkesztốbizottság, az Espaces et sociétés nagyrészt a francia nyelvterületek irányában elkötelezett; a Society and Space pedig az Atlanti-óceán két partján élő angolszász szerkesztók keze nyomán formálódik.

1. TÁBLAZAT

Espaces et sociétés

A megjelent tanulmányok a szerzók hovatartozása szerint

\begin{tabular}{lcccc}
\hline Ország & 1985 & 1986 & 1987 & 1988 \\
& $46 / 47$ & $48 / 49$ & $50 / 51$ & $52 / 53$ és 54/55 \\
\hline & & \multicolumn{3}{c}{ (százalék) } \\
\hline Franciaország & 44 & 85 & 73 & 45 \\
Belgium & - & 4 & - & 6 \\
Svájc & 8 & 8 & 12 & 20 \\
Kanada & 10 & 8 & 12 & 3 \\
Más európai országok & 28 & 4 & 3 & 23 \\
USA/Ausztrália & 10 & - & - & - \\
Egyéb & - & - & - & 3 \\
Szám & 39 & 26 & 33 & 35 \\
\hline
\end{tabular}

\section{TABBLAZAT}

Society and Space

A megjelent tanulmányok a szerzốk hovatartozása szerint

\begin{tabular}{lrrrrr}
\hline & 1984 & 1985 & 1986 & 1987 & 1988 \\
\hline Ország & \multicolumn{5}{c}{ (százalék) } \\
\hline Egyesült Királyság & 34 & 30 & 35 & 50 & 45 \\
USA & 31 & 35 & 32 & 18 & 24 \\
Más európai országok & 15 & 13 & 11 & 21 & 11 \\
Kanada & 10 & 11 & 3 & 7 & 13 \\
Ausztrália & 2 & 2 & 11 & - & 8 \\
Izrael & - & 7 & 3 & - & - \\
Egyéb & 8 & 2 & 3 & 4 & - \\
Szám & 61 & 46 & 34 & 28 & 38 \\
\hline
\end{tabular}


Az Espaces et sociétés hetvenes évekbeli indulása idején az 1968-as diákmozgalmak utórezgései - és azok nyomán a marxizmus elốretörése - nagy hatással voltak a tudományos gondolkodásra Nyugat-Európában. Köztudott, hogy Lefebvre egyike volt a legkiválóbb marxista indíttatású kutatóknak, de fontos tudnunk, hogy annak nem dogmatikus, hanem liberálisabb változatát múvelte (és teszi nyugdíjasként is mind a mai napig). Nyilvánvaló, hogy szemléletének sajátosságai tükröződtek az általa életre hívott folyóirat hasábjain is. A hetvenes években a marxizmus gyorsan lehanyatlott a francia társadalomtudományok müvelói körében. A korábban ez irányban elkötelezett szerzốk számára kiderült, hogy ez az elmélet, amelyet a XIX. században alkottak meg a korabeli társadalmi viszonyok elemzésére, ma már alkalmatlan arra, hogy segítségével a bennünket körülvevố társadalmi jelenségeket is megmagyarázzuk. Egyes kutatók megtartottak bizonyos alapföltevéseket; belỏlük lettek a marxizáló vagy a marxizmus által inspirált társadalomtudósok. Az Espaces et sociétés is egyre inkább eltávolodott a marxizmustól, megjelentetett cikkeinek szemlélete liberálisabb és sokoldalúbb lett.

Ami a Society and Space-t illeti, annak szerkesztối nem kötelezték el magukat egyetlen társadalomelméleti irányzat vagy iskola kizárólagos képviseletére sem, sốt kifejezetten azt vallják, hogy nem lehet egyetlen monolitikus elméleti vagy módszertani konstrukció segítségével magyarázni a társadalmat. Természetesnek tartják, hogy a szerzốk különbözố diszciplínák apparátusával és megközelítésével dolgoznak, ugyanakkor bátorítják a viták egyfajta közös nyelvének kialakítását. Mindazonáltal elmondhatjuk, hogy a Society and Space-ben publikálók zöme baloldali érzületũ, liberális gondolkodó; egyikük-másikuk a neopozitivista, megint mások a strukturalista iskola hívei, de vannak olyanok is, akik a fenomenológia irányába indultak el. A folyóirat szerkesztôi azonban nem akarják elốre kijelölni a gondolkodás pályáit, hisz az mindenképpen valamiféle bezártságot eredményezne.

Mindkét kiadványra igaz, hogy elsősorban a geográfia teoretikus vonalát képviselik, vagyis a közölt írások elméleti problémák fölvetésére és elemzésére vállalkoznak; így az empíria általában csak illusztráció, segédanyag az értelmezéshez. Ezt persze nem úgy kell érteni, hogy szerzổink nem végeznek empirikus vizsgálatokat, de ezek részletes közlésére más szakfolyóiratok vállalkoznak. Noha elốfordulnak olyan cikkek is, amelyek a tér és a társadalom kapcsolatrendszerének legáltalánosabb filozófiai és antropológiai kérdéseit taglalják, az írások többsége azzal foglalkozik, hogy a világ fejlettebb régióiban a különbözố térbeli komplexumok, entitások hogyan reprodukálják önmagukat, illetve, hogy a polgári demokráciák folyamatosan zajló átalakulásai milyen új térbeli szervezôdéseket hoznak létre. A két szerkesztốbizottság másfelól azokat a szerzốket preferálja, akik a társadalom térbeli szervezôdésére vonatkozó elméletek finomítását, megújítását tưzik ki célul, illetôleg a fỏldrajznak a társadalomtudományokba való teljes integrálódásán munkálkodnak.

A társadalom térbelisége is valamiféle totalitás, mint ahogy a társadalom idốbelisége is az, $\mathrm{s}$ a társadalomelméletek kiterjesztése az elốbbi irányba legalább olyan fontos, mint az utóbbiba - vallják a humán geográfia legjelesebb képviselổi, többek között a szóban forgó tudományos orgánumokban is. Sốt, a legmerészebbek egyszerre vetik meg lábukat mindkét pilléren, hisz meggyôzốdésük, hogy a társadalmi jelenségek megértése csak egy tér-idố viszonyrendszerben képzelhetố el. A szerkesztốbizottságok készségesen, ,adnak teret" a tér, az idô és a társadalmi viszonyok kapcsolatrendszerét egyfajta egyensúlyban vizsgáló gondolatoknak. 


\section{TÁBLÁZAT}

Espaces et sociétés

A megjelent tanulmányok szerzôi tudományágak szerint

\begin{tabular}{lcrrc}
\hline Tudományág & 1985 & 1986 & 1987 & 1988 \\
& $46 / 47$ & $48 / 49$ & $50 / 51$ & $52 / 53$ és 54/55 \\
\hline Földrajz & \multicolumn{5}{c}{ (százalék) } \\
Építészet és tervezés & 8 & 12 & 15 & 9 \\
Városi és regionális kutatás & 21 & 12 & 6 & 9 \\
Szociológia és társadalomtudomány & 13 & 4 & 15 & 14 \\
Politológia & 31 & 65 & 52 & 54 \\
Közgazdaságtan & - & 4 & 3 & 6 \\
Egyéb & - & - & 3 & 3 \\
Szám & 28 & 4 & 6 & 3 \\
\hline
\end{tabular}

\section{TÁBLAZAT}

Society and Space

A megjelent tanulmányok szerzổi tudományágak szerint

\begin{tabular}{lrrrrr}
\hline Tudományág & 1984 & 1985 & \multicolumn{1}{c}{1986} & 1987 & 1988 \\
\hline & \multicolumn{5}{c}{ (százzlék) } \\
\hline Földrajz & 46 & 48 & 34 & 43 & 63 \\
Építészet és tervezés & 16 & 24 & 24 & 18 & 8 \\
Városi és regionális kutatás & 15 & 11 & 17 & 11 & \\
Szociológia és társadalomtudomány & 10 & 7 & 17 & 14 & 8 \\
Politológia & - & 2 & - & - & - \\
Közgazdaságtan & 7 & 7 & 3 & 7 & 8 \\
Egyéb & 7 & 2 & 3 & 11 & 3 \\
Szám & 61 & 46 & 29 & 28 & 38 \\
\hline
\end{tabular}

A hasonlóságok mellett azonban a két folyơirat stílusát illetố különbségekre is utalnunk kell. Bár a modern geográfia megteremtésében úttörő szerepet játszottak a francia földrajzosok, késớbb igencsak lemaradtak az angol társadalomföldrajzhoz képest, de még a más, országunkban múvelt társadalomtudományi kutatásokhoz viszonyítva is. Ennek okát nem könnyứ megtalálni. A folyamat végeredménye azonban szembetũnố: Franciaországban a legkiválóbb térbeli kutatások elsốsorban szociológusok és közgazdászok nevéhez fúzỏdnek, míg Angliában a geográfiának jóval magasabb presztízst sikerült kivívnia a hazai társadalomtudományokban. A szigetországban dolgozó földrajzosok számára tehát - mint ahogy ezt már említettem nemcsak az a kérdés, hogy miként építhetnek más tudományok ismereteiból, hanem egyre inkább az, mit kínálhat a humán geográfia a többi társadalomtudományi szférának. Azt, hogy mennyivel intenzívebb kapcsolatot találtak a különféle társadalomelméletek fejlơdésével, mint francia kollégáik, mi sem illusztrálja jobban, mint hogy az angol geográfusok sztárjai jóval gyakrabban hivatkoznak a közelmúlt legnevesebb francia gondolkodói közül például Derridara és Foucault-ra, mint maguk a francia földrajzosok. Mindezek következménye, bár az erőss 
tradíció kialakulásának talán egyik elốzménye is, hogy Angliában a földrajz már a középiskolában felzárkózik az alaptantárgyak közé , $s$ az egyetemeken is magas presztízsứ szak. Ezzel szemben Franciaországban a legtehetségesebb diákok a politológia és a szociológia mellett döntenek a pályaválasztáskor.

Mindkét folyóirat hasábjain nyomon követhetố bizonyos aktualitásra való törekvés is, noha zömében elméleti írásokról van szó. A hatvanas évek óta - amikoris a nyugati világban a társadalom szerkezete élesebben rajzolódott ki, s a mainál könnyebben volt leírható - nagy léptékú átrendezổések mentek végbe, kialakultak azok a formák, amelyeket a posztindusztriális vagy posztmodern jelzôvel szoktak illetni. Úgy tű̉nik, a nyolcvanas évek elejére a nyugati demokráciák társadalmi viszonyai a korábbihoz képest jóval hajlékonyabbakká váltak, következésképp az ezeket magyarázni kivánó elemzéseknek is rugalmasabbá kellett válniuk. A rugalmasság, az új szemléletmódok keresése indította el azt a folyamatot, amelyben mind közelebb kerültek egymáshoz a neves szociológusok és geográfusok által kifejtett gondolatok: közös kiindulóponttá vált annak tételezése, hogy az egyének és a társadalmi csoportok térbelileg is sajátosan tagolt társadalmi viszonyok közt cselekszenek.

\section{TÁBLAZAT}

Espaces et sociétés

A megjelent tanulmányok tárgykörök szerint

\begin{tabular}{|c|c|c|c|c|}
\hline Tárgykör & $\begin{array}{r}1985 \\
46 / 47\end{array}$ & $\begin{array}{r}1986 \\
48 / 49\end{array}$ & $\begin{array}{r}1987 \\
50 / 51\end{array}$ & $\begin{array}{c}1988 \\
52 / 53 \text { és } 54 / 55\end{array}$ \\
\hline & \multicolumn{4}{|c|}{ (százalék) } \\
\hline Társadalomelmélet & 3 & 38 & 4 & 31 \\
\hline \multicolumn{5}{|l|}{ Osztály/Munka } \\
\hline Társadalmi mozgalmak & 3 & - & - & 4 \\
\hline Politika/Állam & - & 13 & 9 & $j$ \\
\hline \multicolumn{5}{|l|}{ Közgazdaságtan/ } \\
\hline Egyenlôtlen fejlődés & - & - & 9 & 4 \\
\hline Etnikum/Kisebbség & 3 & - & - & 4 \\
\hline Nớk & 3 & - & - & - \\
\hline Városok & 9 & 8 & 13 & 23 \\
\hline Lakás & - & - & 9 & 11 \\
\hline Jólét & - & - & 4 & - \\
\hline Építészet/Tervezés & 26 & 8 & 9 & 7 \\
\hline Jog & - & - & - & 4 \\
\hline Közlekedés & 3 & - & 4 & 4 \\
\hline Hírközlés (Kommunikáció) & - & - & 22 & - \\
\hline Szemiotika & 32 & 4 & - & - \\
\hline Kultúra/Ideológia & 3 & 13 & 4 & - \\
\hline Vélemény/Felmérés & 12 & 17 & 9 & - \\
\hline Interjú & 3 & - & - & - \\
\hline Szám & 34 & 24 & 23 & 26 \\
\hline
\end{tabular}




\section{TABBLAZAT}

Society and Space

A megjelent tanulmányok tárgykörök szerint

\begin{tabular}{lcccc}
\hline Tárgykör & 1985 & \multicolumn{1}{c}{1986} & 1987 & 1988 \\
\hline & \multicolumn{4}{c}{ (százalék) } \\
\hline $\begin{array}{l}\text { Társadalomelmélet } \\
\text { Osztály/Munka }\end{array}$ & 21 & 7 & 50 & 4 \\
$\quad$ Társadalmi mozgalmak & 14 & 14 & - & 8 \\
$\begin{array}{l}\text { Politika/Állam } \\
\text { Közgazdaságtan/Ipar }\end{array}$ & - & 10 & 14 & 4 \\
$\quad$ Egyenlótlen fejlódés & 25 & 17 & 14 & 31 \\
Etnikum/ Kisebbség & - & 10 & - & - \\
Városok & 4 & 3 & - & 8 \\
Lakás & - & 3 & 4 & - \\
Jólét & - & 7 & - & - \\
Építészet/Tervezés & 7 & 3 & - & 4 \\
Jog & - & 3 & - & - \\
Közlekedés & - & 3 & - & - \\
Kultúra/Ideológia & - & - & 4 & 27 \\
Vélemény/Felmérés & 25 & 17 & 11 & 15 \\
Interjú & 4 & - & 4 & - \\
Szám & 29 & 26 & 28 & 26 \\
\hline
\end{tabular}

Szerkesztenek-e tematikus számokat a két folyóiratnál? Milyen ötletek alapján, hogyan formálódik egy-egy ilyen szám?

Az Espaces et sociétés eddig csaknem kizárólag tematikus számokra épített. Az ötleteket, témákat általában valamely szerkesztốbizottsági tag indítványozza, szokásaink szerint néhány oldalas összefoglalót juttatva el kollégáihoz. Miután megszületett a döntés, a szerkesztôbizottság felhívást tesz közzé az adott számot megelổzỏen, hogy a leendổ szerzốket orientálja, inspirálja. A folyóirat egyik legsikeresebb tematikus számát nemrégiben a lakás, a lakóterek problematikájának szenteltük, de hasonlóan izgalmas gondolatok gyưltek össze a mozgással, a társadalom térbeli mobilitásával kapcsolatban is, majd pedig a tömegkommunikáció térbeli szervezổéséról. Mivel az Espaces et sociétés eddig csak két számot adott ki évente, ezek - tartalmukban és formájukban egyaránt - inkább tanulmánykötetre emlékeztetnek. Ettôl az évtốl kezdve azonban évi négy szám lát majd napvilágot, és egy közülük valószínúleg azon szerzók írásából áll majd, akik színvonalas cikkel jelentkeznek ugyan, de az nem illeszthetô be a tematikus számokba.

A Society and Space szerkesztốbizottságának tagjait tulajdonképpen baráti szálak füzik egymáshoz, melynek intellektuális elkötelezettség az alapja, nevezetesen a ,térbeli látás” a társadalmi jelenségek magyarázatában. Nincs is állandó székhelye a szerkesztôbizottsági üléseknek, hisz gyakran találkozunk különbözổ tudományos kollokviumokon, konferenciákon, egyetemi kurzusokon. Bár egymástól viszonylag távol, az Atlanti-óceán két partján elszórva 
múködünk, szoros kapcsolatot tartunk egymással - szóban vagy írásban, mikor hogy alakul az életünk -, milyen gondolataink támadnak. llyenformán nem gond a tematikus számok kiötlése és szervezése. A folyóirat évi négy számából kettỏ rendszerint tematikus, bár ez nincs feltüntetve a címlapon, ahogy az az Espaces et sociétés esetében történik. Az elmúlt évben például David Harvey, az egyik legismertebb angolszász földrajzos munkásságáról adtunk ki tematikus számot, amelyben maga a ,téma” is részt vett.

Figyelembe véve a bemutatott szerkesztố megfontolásokat, mutassa be egy kicsit részletesebben, kik és milyen tárgykörökben publikáltak a két folyóirat hasábjain az elmúlt években?

1987-ben az Espaces et sociétés szerzôinek témaválasztása meglehetốsen gazdag volt, még a tematikus számokon belül is. Leginkább a politológiai és a közgazdasági témák foglalkoztatták a szerzôket, de számos tanulmány fordított figyelmet a kommunikációs mechanizmusok és a kultúra egyes kérdéseire. 1988-ban a tematikus számoknak köszönhetốn a városfejlesztés és -építés bizonyult a legnépszerúbb tárgykörnek, az általános társadalomelméleti cikkek elôttt. A folyóirat szerzổinek fele többnyire franciaországi kutató, egyre nổ a Svájcból érkezố írások száma, a maradék hányadban évente változó a kanadai és más, általában franciaajkú európai szerzốk elôfordulása.

A Society and Space-ben 1987-ben megjelent cikkek többsége társadalomelméleti témákat taglalt, míg 1988-ban a gazdaság és a kultúra térbeli struktúrái álltak az érdeklốdés középpontjában. Szinte minden megjelenô számban találhatunk azonban építészeti írásokat, és viszonylag rendszeresen szociológiai jellegû́, a társadalom szerkezetét elemzô munkákat. A folyóiratban publikálók közül minden évben az angol szerzốk alkotják a legnépesebb csoportot, de az angolszász szerzốk aránya együttesen minden számban eléri a kétharmadot. A következõ a sorban Európa többi része (Kelet-Európa általában nem), majd Kanada.

\section{Nem terveznek valamiféle nyitást Kelet- és Közép-Európa felé?}

Nem beszélhetünk nyitásról, mivel sosem zárkóztunk el a közép- és kelet-európai országok elốl. Minden országból szívesen fogadunk, illetve fogadnánk elméleti vagy empirikus értekezéseket. Sốt, mindkét folyóirat két nyelven, angolul és franciául is elfogad javaslatokat. Valamint annak érdekében, hogy Magyarország jobban bekerüljön a nemzetközi tudományos , vérkeringésbe", felkértem Enyedi professzor urat, lépjen be az Espaces et sociétés szerkesztőségébe, amit el is vállalt, s így négy éve a bizottság tagja. A közeljövốben meg is jelenik egy cikke. Nemrég ajánlottam a lengyel Kuklinski professzor egyik értekezését a Society and Space számára, de a publikációról még nem született döntés. 1990-91-ben az Espaces et sociétés tematikus számot készít a kelet-európai országok részvételével. Sajnos azonban annak ellenére, hogy széles körben terjesztettünk cikkek írására vonatkozó felhívást, Magyarországra például tíz példányt küldtem négy különbözố Intézetbe - hat hónap után sem érkezett egyetlen ajánlat sem folyóiratunkhoz, így egy kelet-közép-európai kérdéskört többnyire nyugati szerzốk fognak tárgyalni.

Azt még megjegyezném, hogy mindkét folyóirat alaposan átszữri a beérkezett anyagot. Mivel jóval több tanulmány érkezik a szerkesztôséghez, mint amennyit módunkban áll leközölni, így lehetôségünk van a legjobbakat kiválasztani. A Society and Space kb. 30 \%-át közli a felajánlottaknak, ezek jó részét is javított változatban. Az Espaces et sociétés-nél is hasonló a 
helyzet, az ajánlatok kb. 40 \%-át tudjuk elfogadni. Minden cikket a szerkesztôség legalább két, de többnyire több szakértôje bírál el, sổt néha külsổ szakembert is felkérünk, s a véleményezések után kollektív döntés születik. A személyes problémák elkerülése végett az olvasó (a bíráló) általában névtelenül kapja meg a cikket, így csak tudományos szempontok érvényesülnek a bírálatban. Mindkét folyóirat érdeke, hogy a legjobb szerzốktôl a legújabb gondolatokat adja ki.

Kap-e a két folyóirat pénzbeli vagy másfajta támogatást tudományos kutatóintézetektól, társaságoktól, egyetemektôt, egyéb szervezetektôl? Kik a folyóiratok vásárlói?

Nem, egyik lap sem kap támogatást intézményektốl, vagyis csak a szerkesztôbizottság és a kiadó menedzseli e folyóiratokat. Ez azt jelenti, hogy az eladott példányokból és az elôfizetési díjakból kell fedezni a kiadásokat, sớt még a kiadó számára is valamennyi profitot hozni. Ebbốl általában az teljesül, hogy a vállal kozások többé-kevésbé megtérülnek. Az Espace et sociétésnek 400 elốfizetôjje van és ezen felül körülbelül 400-500 darabot szoktunk eladni, elsósorban egyetemi oktatók és diákok számára. A Society and Space is körülbelül 400-500 elofizetớt tart számon. Mivel a folyóirat viszonylag drága, jobbára csak könyvtárak, intézmények vásárolják, $\mathrm{s}$ ezek azonosak az elôfizetốkkel.

Közismert, hogy vannak konkurrens kiadványok a piacon, így a L'Espace géographique, amely a legszínvonalasabb francia nyelvũ földrajzi lap, az Espaces Temps, ami egy általános társadalomtudományi folyóirat vagy a Progress in Human Geography, amely angol nyelven közöl a legkülönbözóbb témákban írásokat. Említhetem még az Antipode nevũ, radikálisabb szellemiségú folyóiratot, vagy az International Journal of Urban and Regional Research címú szemlét is.

Tervezi-e, hogy a közeljövóben Magyarországra látogat szakmai céllal?

Elốrehaladott tárgyalásokat folytatok szemináriumsorozat szervezésérôl a Regionális Kutatások Központja budapesti Regionális Tudományos Osztályának munkatársaival. Így tehát majdnem bizonyos, hogy 1990 ószén elóadássorozatot tartok majd az említett intézetben a nyugati világban mû̉elt humán geográfia legjelentôsebb iskoláiról, gondolkodóiról, eredményeiról. Addig is szívesen segítek magyarországi kollégáimnak, ha az interjúban bemutatott folyóiratok profiljába illố, színvonalas írásokat kívánnak publikálni.

Budapest/Párizs, 1989 február/június Zentai Violetta 


\section{A Society and Space vitairata: A tér és a társadalomelmélet}

1. A modern földrajz a.19. század végén jött létre, s most, a 20. század végén, széthullóban van.

2. Ez örömteli megállapítás mindazok számára, akik hisznek abban, hogy a térbeli perspektíva a teoretikus gondolkodás és a gyakorlat szempontjából alapvetố a jelen idôszakban.

3. Napjainkban a tér túl fontos ahhoz, semhogy csak a geográfusokra hagyhatnánk.

4. A 20. században a geográfián kívül is van egy közösség, amely ragaszkodik ahhoz, hogy a teret újra integrálja a társadalomelméletbe. A tér mindenütt jelenlévố, s mi mindnyájan geográfusokká válunk.

5. A tér újbóli beépítése a társadalomelméletbe egy bonyolult rombolási és újjáépítési folyamat. E folyamat nem csupán a modern geográfia halálát jelenti, hanem mindazon modern diszciplinákét is, melyek a múlt század végén születtek (szociológia stb.). Nekünk le kell rombolnunk ezeket az ,,emlékmû́veket”, hogy újakat építsünk.

6. Az újjárendezôdés központjában a történelem kritikus szemlélete áll: az idố dominanciája a tér felett a társadalomelméletben, a történelmi magyarázat, szemben a földrajzival. E kritikának az a célja, hogy új episztemológiai egyensúlyt teremtsen bármely társadalomelmélet három alapvetố aspektusa, a tér, az idố és a létezés között. Vagy konkrétabban a tér vagy humán geográfia teremtése; a történelem alakítása és a társadalom felépítése.

7. Három fố út vezet a térnek a társadalomelméletbe való újbóli integrálásához. Ezek úgy is jellemezhetốk mint három, egymáshoz kölcsönösen kapcsolódó újrarendezôdés; nevezetesen az ontológia, a modern világ politikai gazdaságtana és a 20. századi társadalmi átalakulások kulturális logikája. 